\title{
The Total Economic Costs Of Finance Faculty Replacement
}

H. Shelton Weeks, (Email: sweeks@fgcu.edu), Florida Gulf Coast University J. Howard Finch, (Email: jhfinch@fgcu.edu), Florida Gulf Coast University Bradley K. Hobbs, (Email: bhobbs@fgcu.edu), Florida Gulf Coast University

\begin{abstract}
The purpose of this study is to estimate the total economic costs associated with filling a vacated finance faculty line. These economic costs include both explicit and opportunity costs associated with the production process. Hiring costs include explicit costs such as advertising the position and implicit costs such as the opportunity costs of faculty time spent in various search committee activities. In addition, the recent market for finance professors has included a significant markto-market salary component associated with replacing departed faculty with new hires. This paper utilizes survey data from recent finance faculty vacancies at AACSB International accredited schools to estimate the total hiring cost equation.
\end{abstract}

\section{INTRODUCTION}

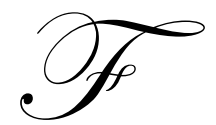

inance faculty salaries have escalated markedly in recent years. At the entry level, the number of $\mathrm{Ph} . \mathrm{D} . \mathrm{s}$ granted in the field of finance nationwide was 151 in 1998. This represented a $20 \%$ decline from peak $\mathrm{PhD}$ generation - $191 \mathrm{PhDs}$ in 1994 (Cowling, 2001). New PhD generation fell due to enrollment limits at PhD-granting institutions, poor academic job markets early in the 1990s and increased opportunity costs associated with multi-year graduate studies. On the other end of the labor supply, as the average age of faculty continues to climb, it is likely that the number of average annual retirements will be increasing. Meanwhile, the demand for business faculty remains strong due to schools experiencing rising undergraduate student enrollments.

A significant factor contributing to the absolute number of vacant finance faculty lines is widespread salary inversion. Existing faculty salaries rarely keep pace with entry-level labor market increases; thus, when a faculty member leaves, the salary required to replace that individual usually contains a premium over the previous salary paid. Salary compression and inversion make the relative attractiveness of faculty movement higher which impacts both the rate of turnover and the magnitude of the costs of turnover for seasoned faculty. All of these issues have combined with the normal transactions costs associated with hiring to raise the costs of filling vacant finance faculty lines.

The purpose of this paper is to estimate the total economic costs of filling a vacant finance faculty position. Survey data from AACSB International accredited colleges of business are used to consider economic replacement costs which include explicit costs, implicit costs, and a salary premium. The data is used to estimate a cost equation to fill a vacant finance faculty line. The results indicate that finance faculty turnover produces significant costs for colleges of business administration.

\section{SAMPLE DATA}

A survey questionnaire was used to develop the data used in this study. Finance department heads at 356 AACSB International accredited colleges and schools of business in the U. S. were surveyed during the 2001-02 academic year to compile complete cost estimates for the most recent finance faculty hiring prior to 2003 . The 80 usable responses yielded a response rate of approximately 22.5\%. Variations on institution size, business school size, and highest degree offered were captured. A copy of the survey instrument and the sample descriptive statistics are available by request from the authors. 


\section{THE COMPONENTS OF TOTAL ECONOMIC HIRING COSTS}

Cascio (2000) provides an analysis of the human resource costs to a firm associated with employee turnover. Applying these concepts to business schools, Finch, Hobbs, and Weeks (2002) defined the total cost equation for hiring finance faculty positions as:

Total Hiring Costs $=$ Turnover Costs + Mark-to-Market Salary Premium

Here, turnover costs include both explicit and implicit costs associated with filling the vacant finance position.

\section{Estimating Explicit Turnover Costs}

The survey results define explicit costs that occurred as part of the position search process. Table 1 details these costs. The "reported cost" data from 2001 were CPI-adjusted to produce an estimate of "current costs." CPI adjustment reported by U.S. Department of Labor Bureau of Labor Statistics for 2001 through 2004 were 2.8\%, 1.6\%, $2.3 \%$, and $2.7 \%$ indicating a total increase of $9.73 \%$ during the 4 -year period. The average explicit costs associated with the replacement search to fill a vacant finance faculty position are $\$ 7,233$.

Table 1: Average Explicit Replacement Costs

\begin{tabular}{|l|c|c|c|}
\hline Item & 2001-02 Reported Cost & CPI Adjustment* & Current Costs \\
\hline Advertising costs & $\$ 642.25$ & $9.73 \%$ & $\$ 705$ \\
Registration costs at meetings & $\$ 650.97$ & $9.73 \%$ & $\$ 714$ \\
Lodging at meetings & $\$ 1,139.14$ & $\mathbf{9 . 7 3 \%}$ & $\$ 1,250$ \\
Transportation to meetings & $\$ 1,148.64$ & $9.73 \%$ & $\$ 1,260$ \\
Meals/entertainment at meetings & $\$ 429.58$ & $9.73 \%$ & $\$ 471$ \\
Rental car at meetings & $\$ 31.76$ & $9.73 \%$ & $\$ 35$ \\
Air travel for candidates to visit & $\$ 1,462.72$ & $9.73 \%$ & $\$ 1,605$ \\
Mileage for candidates to visit & $\$ 72.39$ & $\mathbf{9 . 7 3 \%}$ & $\$ 79$ \\
Rental car for candidates to visit & $\$ 38.99$ & $\mathbf{9 . 7 3 \%}$ & $\$ 43$ \\
Lodging for visits & $\$ 509.33$ & $\mathbf{9 . 7 3 \%}$ & $\$ 559$ \\
Meals/entertainment for visits & $\$ 465.99$ & $\mathbf{9 . 7 3 \%}$ & $\$ 511$ \\
\hline Total Average Explicit Costs & $\$ 6,592.00$ & & $\$ 7,233$ \\
\hline
\end{tabular}

\section{Estimating Implicit Turnover Costs}

Implicit costs result primarily from the personnel hours required to conduct a search process. Table 2 details three major pieces of information that were used to estimate the time commitments that accompany a single search process. These include the average number of hours devoted to specific search tasks, the composition of the search committee by rank, and the number and types of interviews that accompany a typical search. 
Table 2: Average Hours Spent During Search Process Panel A: Time Commitments

\begin{tabular}{|c|c|}
\hline Search Activity & Number of Hours \\
\hline Number of hours developing criteria & 6.11 \\
EEOC compliance & 7.00 \\
Responding to applicants & 33.99 \\
Developing short list & 11.39 \\
Scheduling visits & 8.45 \\
Searching for temporary hire & 35.67 \\
\hline
\end{tabular}

Panel B: Committee Composition

\begin{tabular}{|c|c|}
\hline Faculty Rank & Average Number of Faculty \\
\hline Assistant & 1.8 \\
Associate & 1.5 \\
Full & 1.13 \\
\hline
\end{tabular}

Panel C: Interviews and Visits

\begin{tabular}{|c|c|}
\hline Activity & Average \\
\hline Conferences attended by faculty & 2.16 \\
Faculty attendance per conference & 3.93 \\
Applicants asked to visit & 3.55 \\
Applicants who visited & 3.25 \\
\hline
\end{tabular}

The average finance search committee was comprised of 4.43 members, about equally distributed by rank. Using survey results from Table 2 and AACSB International average salary data for finance faculty for 2004-2005, we estimate the salary for a search committee by the following weighted average:

Average Annual Salary for the Committee $=1.8$ (average assistant salary) +1.5 (average associate salary) +1.13 (average full salary) $\$ 501,339=1.8(\$ 108,300)+1.5(\$ 104,600)+1.13(\$ 132,300)$

A 52-week year reduced by 12 weeks off for summer results in 40 work weeks at five days per week, for a total of 200 work days a year for a faculty member on a nine-month contract. At eight hours per day, this sums to 1600 working hours per year. Dividing the average committee salary by the annual work hours gives an opportunity cost per hour of search committee work: $\$ 501,339 / 1600=\$ 313.34$ per hour. Table 3 summarizes these calculations.

Table 3: Average Salary and Search Committee Composition

\begin{tabular}{|c|c|c|c|c|c|}
\hline Rank & $\begin{array}{c}\text { AACSB-Accredited Mean } \\
\text { Salary }\end{array}$ & $\begin{array}{c}\text { Hours Per } \\
\text { Year }\end{array}$ & $\begin{array}{c}\text { Average Search } \\
\text { Committee }\end{array}$ & $\begin{array}{c}\text { Hourly Wage } \\
\text { Total Hourly } \\
\text { Wage }\end{array}$ \\
\hline Assistant & $\$ 108,300$ & 1600 & 1.8 & $\$ 67.69$ & $\$ 121.84$ \\
Associate & $\$ 104,600$ & 1600 & 1.5 & $\$ 65.37$ & $\$ 98.06$ \\
Full & $\$ 132,300$ & 1600 & 1.13 & $\$ 82.69$ & $\$ 93.44$ \\
\hline Total & & 4.43 & & $\$ 313.34$ \\
\hline
\end{tabular}

In the total sample approximately $50 \%$ of respondents reported using a temporary hire in their search process. The average time reported spent searching for a temporary hire was 35.67 hours. The likelihood of using a temporary hire is limited to the timing of the exiting faculty member's announcement of intention to leave, the prevailing budgetary conditions at the time of the announcement, and the conditions of the labor market. Therefore, the opportunity costs associated with searching for a temporary hire are estimated to be:

35.67 hours per search $\mathrm{x} \$ 313.34$ per hour $=\$ 11,176.84$

Survey reports indicate that an average of 3.93 faculty attended conferences to conduct candidate interviews. Faculty members at the conference do not spend their entire time interviewing candidates, though a major portion of 
the day can be taken in these searches. Assuming only half of the attending faculty are conducting interviews at any point in time and assuming the average search at a conference lasts three days, at eight hours per day, the opportunity costs of interviewing at conferences are estimated to be:

3 days $\mathrm{x} 8$ hours per day $\mathrm{x}(.5) 3.93$ faculty $=47.16$ total hours per conference

The average hire required attendance at 2.16 conferences, so the estimated opportunity costs of conducting conference interviews are:

2.16 conferences $\mathrm{x} 47.16$ hours $\mathrm{x} \$ 313.34$ per hour $=\$ 31,918.57$ per conference

In addition to conference interviews a total of 66.94 hours was required for pre-visit search tasks such as developing position criteria, working with human resources on benefits and EEOC compliance issues, responding to applicant solicitations for the position, narrowing the applicant field, and scheduling candidate visits. Using the hourly opportunity cost of search committee time, the opportunity cost of the search in pre-visit search tasks is computed as:

66.94 hours $\mathrm{x} \$ 313.34$ per hour $=\$ 20,974.98$

There is also the opportunity costs associated with actual campus visits by candidates. The average campus visit lasts 1.5 days, at eight hours per day. In most cases, candidates will conduct a research presentation and go to several meals where more than one faculty member is present. Conservatively, at least one faculty member will accompany the candidate at all times during the business day on campus. Survey respondents indicated the average finance faculty hiring required 3.25 candidate visits:

[(3.25 visits) $\mathrm{x}(8$ hours per day) $\mathrm{x}(1.5$ days $)]=39$ hours of campus visits

Thus, the opportunity costs associated with conducting candidate campus visits is given by:

39 hours per search $\mathrm{x} \$ 313.34=\$ 12,220.26$

Table 4 summarizes the component implicit costs associated with the search process. The summed implicit costs incurred to fill a vacant finance faculty line are $\$ 76,290.65$.

Table 4: Average Implicit Replacement Costs

\begin{tabular}{|c|c|c|c|}
\hline Activity & Total Hours & Cost Per Hour & Total Implicit Costs \\
\hline Searching for temporary hire & 35.67 & $\$ 313.34$ & $\$ 11,176.84$ \\
Pre-visit campus work & 66.94 & $\$ 313.34$ & $\$ 20,974.98$ \\
Conference interviews & 101.87 & $\$ 313.34$ & $\$ 31,918.57$ \\
Candidate campus visits & 39.00 & $\$ 313.34$ & $\$ 12,220.26$ \\
\hline Total & & & $\$ 76,290.65$ \\
\hline
\end{tabular}

\section{Estimating The Mark-To-Market Salary Premium}

Hobbs, Weeks and Finch (2005) estimate the average mark-to-market salary premium, across all ranks, required to adjust a vacant finance faculty line to market salaries. Of the sixty-eight schools responding to this survey question, 58 filled their most recent vacant finance faculty position by hiring at the rank of assistant professor. The average salary adjustment across all ranks was $\$ 9,653$. Salaries for new hires in finance at the rank of assistant at accredited colleges increased by approximately $3.5 \%$ per year across all ranks in the three years since 2002, according to salary data reported by AACSB International. Factoring in this adjustment, the mark-to-market salary premium incurred in 2005-06 by accredited colleges replacing departed finance faculty with an assistant professor should be approximately $\$ 10,700$. 


\section{ESTIMATING THE TOTAL HIRING COST EQUATION}

The explicit and implicit costs are incurred on a by search basis whereas the mark-to-market premium would be incurred on a one time basis (upon actual hire.) Additionally, the explicit and implicit costs as incurred represent sunk costs associated with the search process but the mark-to-market premium represents an ongoing payment in perpetuity for the institution. Valuing the perpetuity would require choosing an appropriate discount rate, compounding expected salary increases over time, estimating longevity in the slot and a number of other variables that are beyond the scope of this inquiry. Here, a strictly conservative approach to the mark-to-market premium is employed. Treating the mark-to-market salary premium as a single, one-time component, and restating equation 1 to recognize both explicit and implicit turnover costs, the total economic hiring cost equation is estimated to be:

Total Economic Hiring Costs = Explicit Turnover Costs + Implicit Turnover Costs + Mark-to-Market Salary Premium

Using the data from Tables 1 and 4 along with the estimated salary premium, the survey results indicate a total hiring cost estimate for filling a finance faculty vacancy as follows:

Total Economic Hiring Costs $=\$ 7,233+\$ 76,290.65+\$ 10,700$

Total Economic Costs for New Finance Faculty Hire $=\$ 94,223.65$

\section{SUMMARY AND CONCLUSIONS}

The search for faculty is an important and strategic component of decision-making in all colleges of business. This study focuses specifically on AACSB International accredited colleges and universities searching for finance faculty. The search process represents significant commitments of time and energy for those on the hiring side, yet the typical conversation about new hires focuses exclusively on the escalating salaries. While this is true, the mark-tomarket premium represents just one of the costs of the search process. Labor market pressures are extending into all ranks and across all institutions, yet the literature to date has not fully explored the true economic costs of the search process. Previous work has defined the total hiring cost equation and estimated the salary premium required to fill a vacant finance faculty line. This paper extends the literature on faculty turnover by estimating both the explicit and implicit costs associated with the replacement search process.

The methodology used is conservative in two ways; first, the mark-to-market premium is treated as a onetime cost whereas, in reality, this premium clearly represents a perpetual increase in the cost of the faculty line. Second, the estimate is for one single search and some proportion of these searches fail. Each time a search fails the explicit and implicit components of the total economic hiring costs are incurred repeatedly.

In addition, views of what the appropriate cost calculations should be may differ among administrators and faculty members. From an administrative perspective there may be a tendency to ignore any implicit costs and to focus on the explicit costs and the mark-to-market premium. A faculty member may view the most pertinent costs to be the implicit or opportunity costs, including time spent in service to the search committee. Additionally, faculty morale may be adversely affected when search committee members participate in the hiring of new professors at market wages that often result in salary inversion. Finally, there is a cultural impact that may also be acknowledged; new faculty must be incorporated into the culture of the institutions in which they are hired. Mentoring and assimilation are part of the job senior faculty undertake, but again they represent opportunity costs in terms of other alternative activities. Ultimately, while the total economic hiring cost equation estimated in this paper indicates economic costs of approximately $\$ 94,000$ to the institution, they do not capture all costs associated with faculty turnover. Nevertheless, this research indicates that business schools incur a heavy financial liability when a finance faculty member leaves the college and a new search process is required to find a replacement. 


\section{REFERENCES}

1. AACSB International - The Association to Advance Collegiate Schools of Business. AACSB International 2001-2002 Salary Survey Report, (December, 2001).

2. AACSB International - The Association to Advance Collegiate Schools of Business. AACSB International 2002-2003 Salary Survey Report, (December, 2002).

3. AACSB International - The Association to Advance Collegiate Schools of Business. AACSB International 2003-2004 Salary Survey Report, (December, 2003).

4. AACSB International - The Association to Advance Collegiate Schools of Business. AACSB International 2003-2004 Salary Survey Report, (December, 2004).

5. Cascio, W. F. Costing Human Resources: The Financial Impact of Behavior in Organizations (Cincinnati, OH, 2000), $4^{\text {th }}$ Edition, South-Western Publishing.

6. Cowling, J. F. Supply and Salary Trends for New Finance Doctorates, The Journal of Accounting and Finance Research, Working Paper, (Fall, 2002).

7. Eaton, T. V. and J. R. Nofsinger. The New and Relocating Finance Faculty Market: Factors Affecting Job Selection, Financial Practice and Education, (Spring/Summer, 2000), 99-110.

8. Finch, J., B. Hobbs, and H. Weeks. The Costs of Hiring for Finance Faculty Positions, Journal of Accounting and Finance Research, (Summer II, 2002), 43-51.

9. Hobbs, B., H. Weeks, and J. Finch. Estimating the Mark-to-Market Premium Required to Fill Vacant Business School Faculty Lines: The Case of Finance, Journal of Education for Business, Volume 80, Number 5, May/June 2005, 253-258

\section{NOTES}

